\title{
Histopathological Safety Evaluation of Newly-Developed MgO SEALER
}

\author{
K. Nakano ${ }^{1,2,6}$, M. Tomida3,6, M. Sato ${ }^{4}$, S. Matsuura ${ }^{5,6}$, A. Yamamoto ${ }^{4,6}$, E. Kasahara ${ }^{4}$, T. Kawakami1,6 \\ ${ }^{1}$ Hard Tissue Pathology Unit, Matsumoto Dental University Institute for Oral Science, Shiojiri, Japan \\ ${ }^{2}$ Department of Oral Pathology, Matsumoto Dental University School of Dentistry, Shiojiri, Japan \\ ${ }^{3}$ Department of Oral Physiology, Matsumoto Dental University School of Dentistry, Shiojiri, Japan \\ ${ }^{4}$ Department of Endodontics and Operative Dentistry, Matsumoto Dental University School of Dentistry, Shiojiri, Japan \\ ${ }^{5}$ Department of Biology, Matsumoto Dental University School of Dentistry, Shiojiri, Japan \\ ${ }^{6}$ Matsumoto Dental University Graduate School of Oral Medicine, Shiojiri, Japan
}

\begin{abstract}
We aimed to evaluate the subcutaneous tissue reaction to a newly-developed $\mathrm{MgO}$ Sealer for root canals. We injected the experimental material and three existing control materials into the dorsal area of 43 male ddY mice. One week and 12 weeks after embedding, the tissue surrounding the embedding sites was removed and histopathological examination was performed. The results demonstrate that the basic histopathological reaction is the formation of fibrous capsules consisting of granulation tissue around the experimental and control embedded materials. Based on our results, we believe that the newly-developed $\mathrm{MgO}$ Sealer is as safe as the existing control materials and can be considered for dental use as a root canal sealer.
\end{abstract}

Key words: tissue reaction; histopathological evaluation; root canal sealer; magnesium oxide

\section{INTRODUCTION}

There are numerous materials used in the dental root canal, icluding medications, root canal filling materials and sealers. Endodontic sealers are needed to fill unavoidable spaces between the solid filling materials and the root canal walls, and should be both biologically acceptable and able to bond to dentin.

We have developed a new magnesium oxide $(\mathrm{MgO})$ sealer, usable as a root canal sealer for endodontic treatment. Because the material is used in vivo, it is necessary to evaluate the tissue reaction according to ISO standard 10993-6 [1, 2]. In the present investiga- tion, we compared the local effects after implantation of the above-mentioned newly-developed material with those of some existing products.

\section{Materials AND METHODS}

\section{Materials}

The materials to be examined include the experimental $\mathrm{MgO}$ Sealer (MS: Neo Dental Chemical Products, Co, Ltd, Tokyo, Japan) and the control, Finapec APC (FP: produced by Kyocera, Kyoto, Japan), Sealapex (SP: produced by Kerr Corp, Orange, CA, USA) and AH Plus (AH: produced by Dentsply De Trey Gmbh, Konstanz, Germany). The materials were formed into discoid $6 \mathrm{~mm}$ in the diameter, and the materials were prepared in the following thickness: NM, 0.86mm; FP, $0.75 \mathrm{~mm}$; SP, $0.80 \mathrm{~mm}$; and $\mathrm{AH}, 0.77 \mathrm{~mm}$. The fundamental data of examined materials is shown in Table 1.

\section{ANIMALS}

A total of 43 male 9-week-old ddY mice weighing about $35 \mathrm{~g}$ (30-40g) each were purchased from Japan SLC Inc. (Hamamatsu, Japan). The animals were kept in plastic cages with a floor mat (Paper Clean: Peparlet Co., Ltd., Shizuoka, Japan) in an air-conditioned room with water and solid diet (Picolab Rodent Diet 20: Japan SLC Inc., Hamamatsu, Japan) during the experimental periods, which lasted 12 weeks. The Matsumoto Dental University Committee for Animal Experimentation approved the study.

Table 1. Main Components of Experimental and Control Materials.

\begin{tabular}{ll|l}
\hline & Materials & Main Components \\
\hline Experimental & MgO Sealer & zinc oxide, magnesium oxide, bismuth oxide, methyl salicylate, guaiacol \\
\hline Control & Finapec APC & hydroxyapatite, magnesium oxide, zinc oxide, bismuth subcarbonate, guaiacol, eucalyptol \\
& Sealapex & $\begin{array}{l}\text { Isobutyl salicylate resin, silicon dioxide, bismuth trioxide, titanium dioxide pigment, } \\
\text { N-ethyl toluene sulfoamide resin, zinc oxide, calcium oxide }\end{array}$ \\
& AH Plus & Diepoxide, calcium tungstate, zirconium oxide, aerosil, pigment, 1-adamantane amine, \\
& NN'-dibenzyl-5-oxa-nonandiamin-1,9, TCD-diamine, silicone oil
\end{tabular}




\section{Methods}

Prior to the examination, inhalation anesthesia was used with an isoflurane (Isoflu: Dainippon Sumitomo Pharma Co., Osaka, Japan) and gas-air mixture (4.0\% concentration). Immediately after the dorsal area of the mice was disinfected with $70 \%$ ethanol, the incision was made and the materials were injected subcutaneously into the connective tissues. The skin surface at the incision site was sutured using suture string. The site was marked every 2 weeks until the final examination period at 12 weeks (Table 2).

Table 2. Experimental Periods and Number of Animals.

\begin{tabular}{ll|ll|c}
\hline & Periods & 1 week & 12 weeks & Total \\
\hline Experimental & $\mathrm{MgO}$ Sealer & 5 & 4 & 9 \\
\hline Control & Finapec APC & 6 & 6 & 12 \\
& Sealapex & 6 & 5 & 11 \\
& AH Plus & 5 & 6 & 11 \\
\hline \multicolumn{5}{r}{} \\
\hline
\end{tabular}

At 1 week and 12 weeks after injection, 4-6 mice from each group were anesthetized with isoflurane and gas-air mixture, and the tissue surrounding the injection sites were excised. The excised tissues were immediately fixed in $4 \%$ paraformaldehyde $/ 0.5 \mathrm{M}$ phosphate buffered solution, embedded in paraffin, and sections prepared.

The tissue sections were stained with hematoxylin and eosin and examined by light microscopy for histopathological changes. We followed the International Organization for Standardization (ISO) guidelines for evaluating the local effects of injection materials.

\section{RESULTS}

\section{Experimental MgO SEALER [MS]}

Histopathologically, according to observation of the 1-week specimens, the embedded MS was slightly broken, and a dark brown or black granulated structure was observed, sometimes with eosin-stained amorphous substances. Some substances were peeled off from the slide glasses. At the periphery of these materials, a layer of necrotic tissue was formed, which showed a comparatively eosin-stained uniform structure (Fig. 1-a). Under the necrotic tissue, fibroblasts proliferated and formed granulation tissue (Fig. 1-b). In the granulation tissue, a small amount of bleeding was evident.

In the 12-week specimens, around the peripheral necrotic tissue of the MS, macrophages were greatly evident in the proliferating granulation tissues. The cytoplasms of macrophages contained many granular structures (Fig.1-c), suggesting phagocytosis of the MS (Fig. 1-d).

\section{Control Materials}

Material \#1: Finapec APC [FP]

In 1-week specimens, the embedded material FP, which was observed as eosin-stained fine granular sub- stances (Fig. 2-a), was encapsulated by comparatively thick granulation tissues with rich inflammatory cell infiltration but without neutrophilic leucocytes (Fig. 2b). In the granulation tissues, fibroblast proliferation was evident, having some enlarged capillaries showing hyperemia.

In 12-week specimens, inflammatory cell infiltration almost disappeared in the proliferated granulation tissue forming around the embedded FP; however, there were some inflammatory cell infiltration and hyperemia in the granulation tissues (Fig. 2-c). Fibrosis gradually occurred in the granulation tissues, but there were some inflammatory cell infiltration and hyperemia in localized regions (Fig. 2-d).

Material \#2: Sealapex [SP]

In 1-week specimens, the embedded material SP was observed as eosin-stained and/or dark-brown/black fine granular combined structures (Fig. 3-a). The surrounding tissue consisted of lamellar fibrous granulation tissues with slightly necrotic changes. There were almost no infiltrations in the fibrous tissues (Fig. 3-b).

Upon removal of the 12 -week specimens, the embedded SP was not observed as a block structure. According to naked eye observation, some dark brown pigmentation was noted on the proliferated granulation tissue masses. As observed histopathologically, small granulation tissue masses were evident, and the phagocytosed embedded materials were confirmed as fine granular brown pigments within the macrophages in the granulation tissues (Fig. 3-c). Furthermore, some hematoxylin-deeply stained calcified structures were evident (Fig. 3-d).

\section{Material \#3: AH Plus [AH]}

In 1-week specimens, there was observed granulation tissue around the embedded material AH (Fig. 4-a). The material contact surface of the granulation tissues was composed of quite thin fibrous capsules, in which comparative strong inflammatory cell infiltrations appeared, mainly infiltrations of lymphocytes and plasma cells. In localized regions, there were some proliferated capillaries and histopathological features of hyperemia (Fig. 4-b).

In 12-week specimens, inflammatory cell infiltration had almost disappeared in the fibrous tissues which encapsulated the embedded AH (Fig. 4-c). The material-contact surface of the fibrous capsule tissue was quite thin at first, and had almost no inflammatory cell infiltration (Fig. 4-d).

\section{Discussion}

Successful endodontic treatment depends on the opening of the pulp chamber, cleaning, irrigation or application of medication, and obturation of the root canal system. After that, the irrigated root canal is then filled with paste material or is obturated with solid materials such as gutta-percha points using a sealer [3, 4]. Various sealers have been produced, each containing different components. One such product, a mixture of calcium hydroxide, zinc oxide, guaiacol and magnesium oxide, is used as medication root canal filling material and sealer $[5,6]$. Because sealer contacting the periodontal 

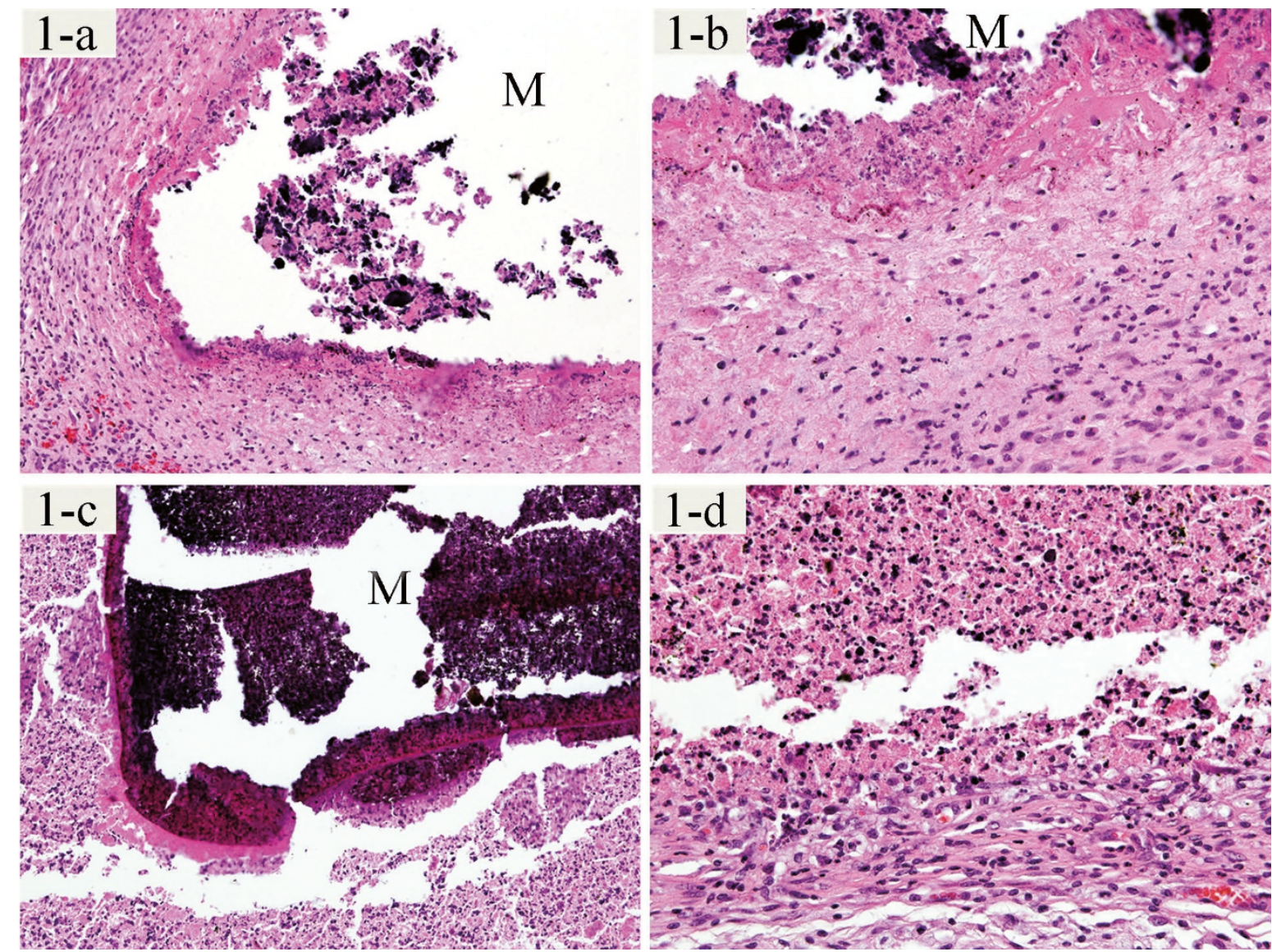

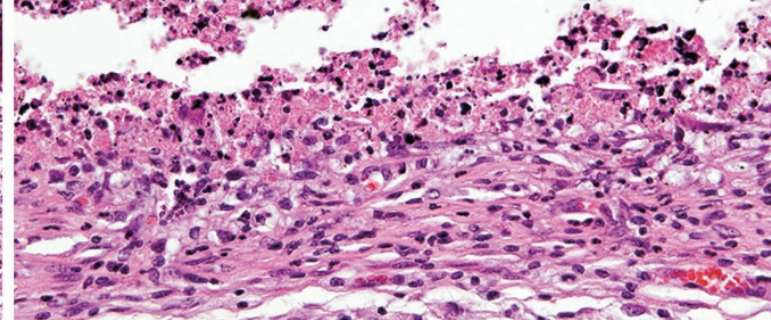

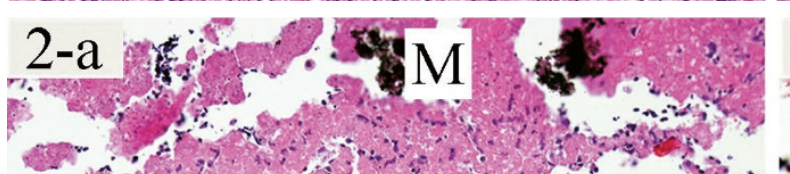

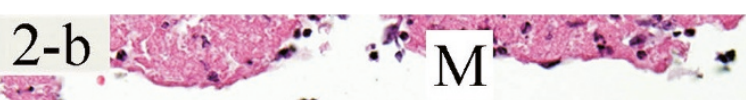
Het.
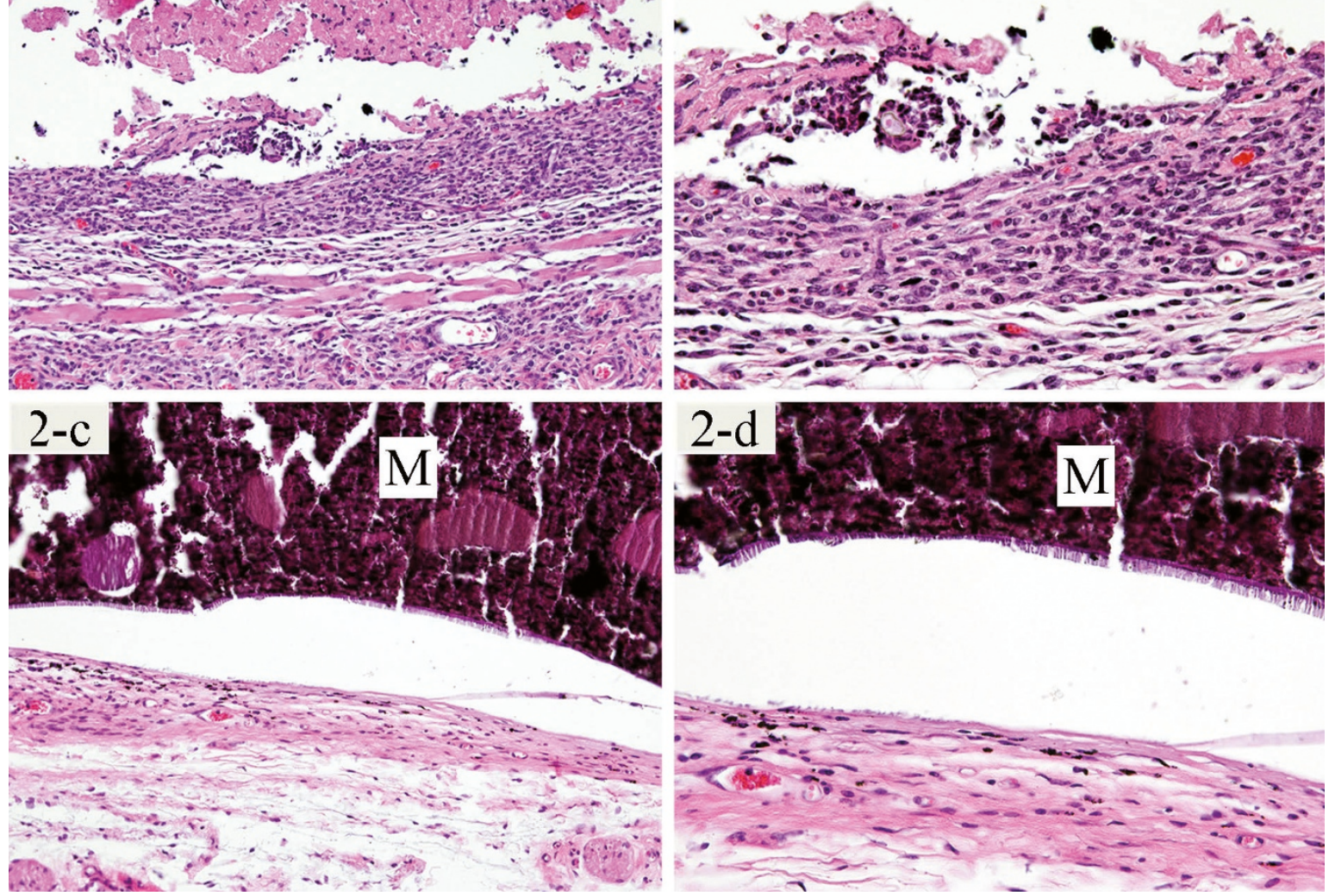

Fig. 1. Experimental (MS) specimen. a: 1-week specimen, x 50; b: 1-week specimen, x 100; c: 12-week specimen, x 50; d: 12-week specimen, $\mathrm{x} 100$.

Fig. 2. Control \#1 (FP) specimen. a: 1-week specimen, x 50; b: 1-week specimen, x 100; c: 12-week specimen, x 50; d: 12week specimen, $\mathrm{x} 100$. 

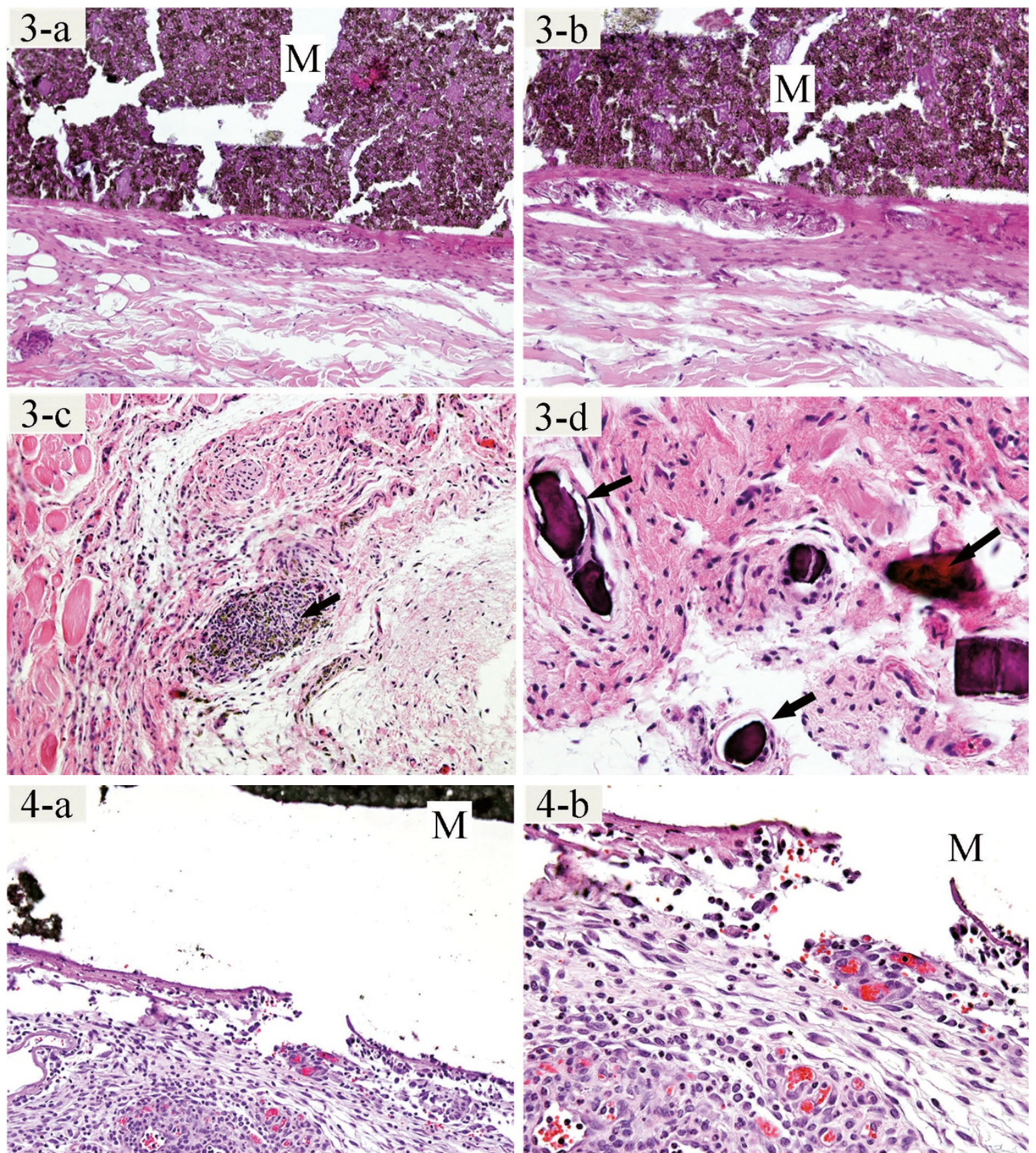

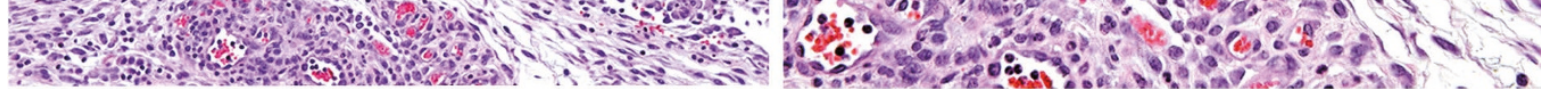

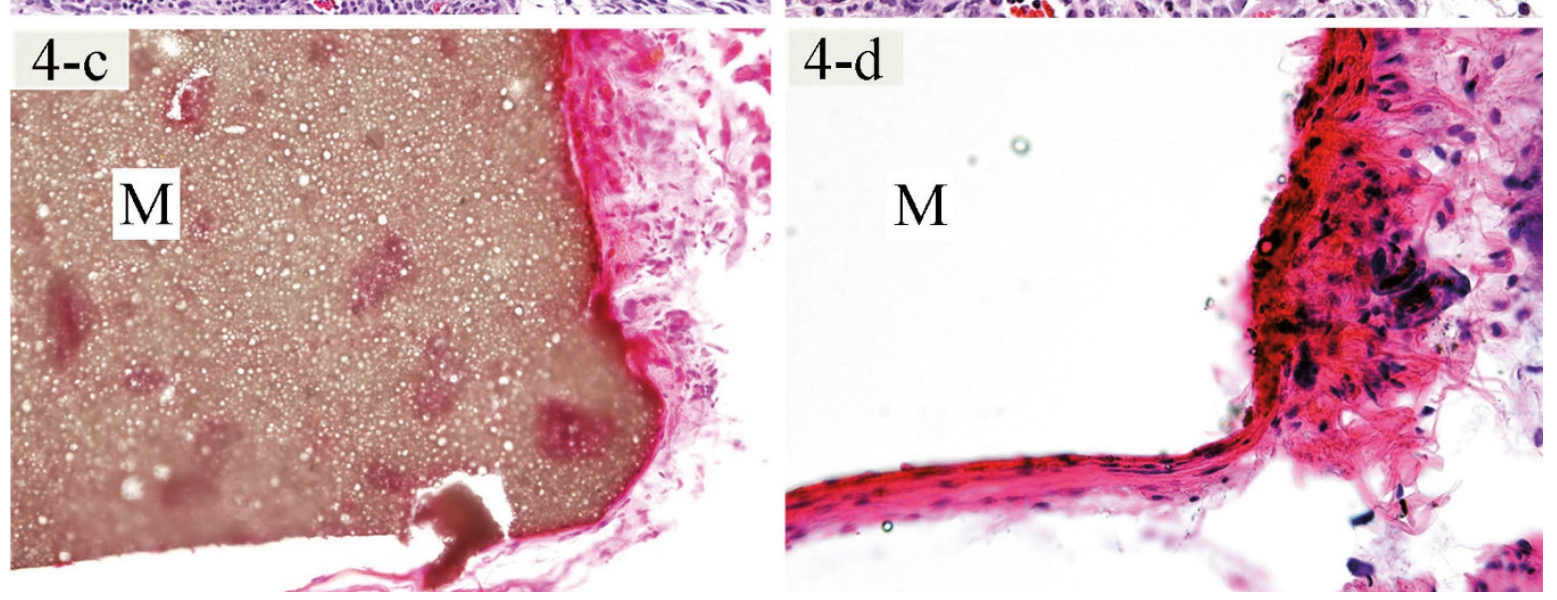

Fig. 3. Control \#2 (SP) specimen. a: 1-week specimen, x 50; b: 1-week specimen, x 100; c: arrow: granular fine pigments, 12-week specimen, x 50; d: arrows: calcified materials, 12-week specimen, x 100.

Fig. 4. Control \#3 (AH) specimen. a: 1-week specimen, x 50; b: 1-week specimen, x 100; c: 12-week specimen, x 50; d: 12 week specimen, x 100 . 
tissues through the apical foramen may generate different reactions in the tissues, it is important to select a suitable material for endodontic treatment for longterm success. For instance, Khashba et al. (2011) examined a newly-developed calcium phosphate-based sealers by histopathological comparison with the commercially available calcium hydroxide-based sealer Acroseal [6]. Other reports have described tissue reactions to various materials as well as biocompatibilities, using commercially-available sealers such as Acroseal, Sealapex, CRCS, AH-26, Tubli Seal, RoekoSeal, AHPlus, Canals, and Finapex APC [7, 8, 9, 10, 11, 12, 13].

For our new magnesium oxide containing paste, $\mathrm{MgO}$ Sealer, MS, we selected magnesium oxide as a component based on the findings of Maeda [14], who described the tissue reaction of magnesium oxide as follows. Magnesium oxide caused few symptoms and exerts a very slight irritating influence to the tissues. It is, therefore, considered very useful as a basic material in endodontic therapy.

Our present examination of 1-week specimens showed slightly broken MS as dark brown or black granulated, and at the periphery of MS, a layer of necrotic tissue was formed. The phenomenon was considered to occur due to the magnesium oxide component; however, beneath the necrotic tissue, there were numerous fibroblastic tissues. This seems to indicate that the irritation caused MS is comparatively less than that of calcium hydroxide sealers [5]. In SP specimens at 12 -weeks, the embedded materials were broken in the proliferated granulation tissues and the macrophage's phagocytosis figures and calcified materials were evident in the tissues, features which have also been noted by Hauman and Love [17]. The calcification was thought to be caused by the calcium oxide component. Furthermore, there was little bleeding in the granulation tissue formation in 1-week specimens, which also indicates the improved biocompatibility. Regarding the 12-week specimens, the features of macrophages showed aggressive repair. This means the component does not cause any damage even though it is not phagocytosed by the macrophages. Granulation tissue rich in cells proliferates around the embedded site.

In conclusion, we examined local effects through the subcutaneous tissue reaction to a newly-developed $\mathrm{MgO}$ Sealer using three existing control materials, and based on our results, we believe that the new developed material is as safe as three control materials and is adequate for use within root canals.

Acknowledgments: The authors thank Professor DM Carlson of Matsumoto Dental University, for his critical reading of the manuscript.

\section{REFERENCES}

1. Upman PJ: ISO 10993-6: Test for local effects after implantation. BONEZone 2006; 5(1): 50-52.

2. International Organization for Standardization (ISO): Biological Evaluation of Medical Devices - Part 1: Evaluation and Testing, ISO 10993-1:2003 (E). Geneva, Switzerland. 2003.

3. Ochiai T, Shimizu T, Kurihara S, Hasegawa H and Kawaka$\mathrm{mi}$ T: Tissue reaction to calcium hydroxide paste for root canal filling. J Matsumoto Dent Univ Soc 2003; 29: 258-263.
4. Shimizu T, Ochiai T, Kurihara S, Hasegawa H and Kawakami T: Tissue reaction to a calcium hydroxide paste developed for root canal filling. J Matsumoto Dent Univ Soc 2003; 29: 264-267.

5. Shimizu T, Kawakami T, Ochiai T, Kurihara S, Hasegawa $\mathrm{H}$ : Histopathological evaluation of subcutaneous tissue reaction in mice to a calcium hydroxide paste developed for root canal fillings. J Int Med Res 2004; 32: 416-421.

6. Khashaba RM, Moussa MM, Chutkan NB and Borke JL: The response of subcutaneous connective tissue to newly developed calcium phosphate-based root canal sealers. Int Endod J 2011; [doi: 10.111/j.1365-2591.2010.0183 6.x.]

7. Gomes-Filho JE, Bernabe PF, Nery MJ, Otoboni-Filho JA, Dezan-Junior E, de Moraes Costa MM, de Faria MD, Watanabe $\mathrm{S}$ and Gomes AC: Reaction of rat connective tissue to a new calcium hydroxide-based sealer. Oral Surg Oral Med Oral Pathol Oral Radiol Endod 2008; 106; e71-76.

8. Holland R, de Souza V, Nery MJ, Bernabe FE, Filho JA, Junior ED and Murata SS: Calciumsalts deposition in rat connective tissue after the implantation of calcium hydroxidecontaining sealers. J Endod 2002; 28: 173-176.

9. Veloso HH, de Santos RA, de Araujo TP, Leonardi DP and Barattto Filho F: Histological analysis of the biocompatibility of three different calcium hydroxide-based root canal sealers. J Appl Oral Sci 2006; 14: 376-381.

10. Economides N, Kotsaki-Kovatsi VP, Poulopoulos A, Kolokuris I, Rozos G and Shore R: Experimental study of the biocompatibility of four root canal sealers and their influence on the zinc and calcium content of several tissues. J Endod 1995; 21: 122-127.

11. Mittal M, Chandra S and Chandra S: Comparative tissue toxicity evaluation of four endodontic sealers. J Endod 1995; 12: 622-624.

12. Silva-Herzog D, Ramirez T, Mora J, Pozos AJ, Silva LA, Silva RA and Nelson-Filho P: Preliminary study of inflammatory response to subcutaneous implantation of three root canal sealers. Int Endod J 2011; [doi: 10.111/ j.1365-2591. 2010.01849.x.]

13. Maseki T, Yasumura K, Nanba I, Kobayashi F and Nakamura H: Alterations in macrophages after exposure to root canal filling materials. J Endod 1996; 22: 450-454.

14. Maeda K: Biological evaluation of magnesium oxide-guaiacol compounds in endodontics - histopathological and clinico-pathological studies. Jpn J Conserv Dent 1991; 34: 15951621.

15. Nakagawa K, Ariizumi Y, Furusawa M, Yamaguchi K, Ito A and Asai Y: New hydroxyapatite root canal sealer Finapec APC 2. Characteristics and clinical application. Jpn Dent Rev 1990; 573: 137-147.

16. Minagawa M, Yamaguchi K, Tobe O, Yuzawa K, Yoshida T, Furusawa M, Nakagawa K, Ito A: Experimental studies on the sealing properties of various kinds of root canal sealers in vitro (Part 3). J Tokyo Dent Coll Soc (Shikwa Gakuho) 1989; 89: 669-679.

17. Hauman CHJ and Love RM: Biocompatibility of dental materials used in contemporary endodontic therapy: a review. Part 2. Root-canal-filling materials. Int Endod J 2003; 36: 147-160.

Received: June 30, 2011 / Accepted: July 13, 2011

Address for correspondence:

Toshiyuki Kawakami, PhD, Professor

Hard Tissue Pathology Unit

Matsumoto Dental University

Graduate School of Oral Medicine

1780 Hirooka-Gobara

Shiojiri,

399-0781 Japan

Phone and Fax: +81-263-51-2035

E-mail:kawakami@po.mdu.ac.jp 